University of Nebraska - Lincoln

DigitalCommons@University of Nebraska - Lincoln

\title{
Reduction in carbon uptake during turn of the century drought in western North America
}

\author{
Christopher R. Schwalm \\ Northern Arizona University, christopher.schwalm@nau.edu \\ Christopher A. Williams \\ Clark University, cwilliams@clarku.edu \\ Kevin Schaefer \\ University of Colorado at Boulder, kevin.schaefer@nsidc.org \\ Dennis Baldocchi \\ University of California at Berkeley, baldocchi@berkeley.edu \\ T. Andrew Black \\ University of British Columbia, andrew.black@ubc.ca \\ See next page for additional authors
}

Follow this and additional works at: https://digitalcommons.unl.edu/usdaarsfacpub

Schwalm, Christopher R.; Williams, Christopher A.; Schaefer, Kevin; Baldocchi, Dennis; Black, T. Andrew; Goldstein, Allen H.; Law, Beverly E.; Oechel, Walter; Tha Paw U, Kyaw; and Scott, Russel L., "Reduction in carbon uptake during turn of the century drought in western North America" (2012). Publications from USDA-ARS / UNL Faculty. 1123.

https://digitalcommons.unl.edu/usdaarsfacpub/1123

This Article is brought to you for free and open access by the U.S. Department of Agriculture: Agricultural Research Service, Lincoln, Nebraska at DigitalCommons@University of Nebraska - Lincoln. It has been accepted for inclusion in Publications from USDA-ARS / UNL Faculty by an authorized administrator of DigitalCommons@University of Nebraska - Lincoln. 


\section{Authors}

Christopher R. Schwalm, Christopher A. Williams, Kevin Schaefer, Dennis Baldocchi, T. Andrew Black, Allen H. Goldstein, Beverly E. Law, Walter Oechel, Kyaw Tha Paw U, and Russel L. Scott 


\title{
Reduction in carbon uptake during turn of the century drought in western North America
}

\author{
Christopher R. Schwalm ${ }^{1 \star}$, Christopher A. Williams ${ }^{2}$, Kevin Schaefer ${ }^{3}$, Dennis Baldocchi ${ }^{4,5}$, \\ T. Andrew Black ${ }^{6}$, Allen H. Goldstein ${ }^{4,5,7}$, Beverly E. Law ${ }^{8}$, Walter C. Oechel ${ }^{9,10}$, Kyaw Tha Paw U ${ }^{11}$ \\ and Russel L. Scott ${ }^{12}$
}

Fossil fuel emissions aside, temperate North America is a net sink of carbon dioxide at present ${ }^{1-3}$. Year-to-year variations in this carbon sink are linked to variations in hydroclimate that affect net ecosystem productivity ${ }^{3,4}$. The severity and incidence of climatic extremes, including drought, have increased as a result of climate warming ${ }^{5-8}$. Here, we examine the effect of the turn of the century drought in western North America on carbon uptake in the region, using reanalysis data, remote sensing observations and data from global monitoring networks. We show that the area-integrated strength of the western North American carbon sink declined

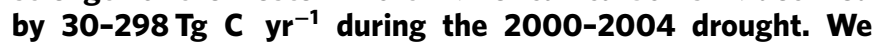
further document a pronounced drying of the terrestrial biosphere during this period, together with a reduction in river discharge and a loss of cropland productivity. We compare our findings with previous palaeoclimate reconstructions ${ }^{7}$ and show that the last drought of this magnitude occurred more than $\mathbf{8 0 0}$ years ago. Based on projected changes in precipitation and drought severity, we estimate that the present mid-latitude carbon sink of 177-623 $\mathrm{Tg} \mathrm{C} \mathrm{yr}^{-1}$ in western North America could disappear by the end of the century.

From 2000 to 2004 , western North America $\left(25^{\circ}-50^{\circ} \mathrm{N}\right.$, $100^{\circ}-125^{\circ} \mathrm{W}$ ) experienced a protracted drought (Fig. 1), the most extreme five-year average Palmer Drought Severity Index (PDSI, see Methods) event since 1200. The drought was evident in several hydroclimatic indicators: precipitation, soil moisture, evaporative fraction and latent heat (Fig. 1). Although precipitation recovered in the latter part of 2004 this did not ameliorate the drought condition until 2005 owing to the inherent lag between precipitation inputs and terrestrial biosphere response after multiyear precipitation deficits. Similarly, the cumulative effect over five consecutive drought years led to a clear reduction in water availability as indicated by decreased runoff in all major water basins of the western United States (Fig. 2). The California and Upper Colorado basins had 50\% less runoff during the drought with the Lower Colorado River Basin showing a $10 \%$ reduction in runoff persisting through 2007 . The drought's

effect was equally evident in highly managed croplands. Crop productivity in 2,383 counties of the western United States ${ }^{9}$ declined $5 \%$ or $29 \mathrm{TgC} \mathrm{yr}^{-1}$ (from 551 to $521 \mathrm{TgC} \mathrm{yr}^{-1}$ ) during the turn of the century drought, with the largest reduction in 2002 (Fig. 2).

Consistent with these large-scale patterns, carbon uptake was suppressed at 10 of 15 eddy-covariance flux tower sites from the global FLUXNET network (Supplementary Table S1). Despite differences in ecosystem types, edaphic and climatic conditions, temporal extent of flux tower records, disturbance impacts ${ }^{10}$ and the spatial heterogeneity of drought ${ }^{11}$, the flux tower site observatory exhibited a coherent, integrated response to the turn of the century drought (Supplementary Fig. S1 and Table S2) with a network-integrated decrease (less uptake) in net ecosystem productivity (NEP) of $-63 \mathrm{~g} \mathrm{C} \mathrm{m}^{-2} \mathrm{yr}^{-1}$ (95\% confidence interval: -20 to $\left.-139 \mathrm{~g} \mathrm{C} \mathrm{m}^{-2} \mathrm{yr}^{-1}\right)$. In grassland and evergreen needleleaf forests, the drought reduced gross primary productivity (GPP) more than ecosystem respiration resulting in a reduction in net $\mathrm{CO}_{2}$ uptake (Fig. 3), consistent with expectation ${ }^{12}$. In contrast, woody savannas exhibited an increase in net $\mathrm{CO}_{2}$ uptake largely owing to pronounced reduction in ecosystem respiration. This supports the reported reduction of decomposition during drought ${ }^{13}$ (Fig. 1 and Supplementary Table S2) and the reduced coupling of GPP from precipitation for woody vegetation owing to access to deep water storage ${ }^{14}$.

Micrometeorological stations also recorded decreased latent heat flux $(L E)$ for each of the three land-cover classes but with markedly different magnitudes (Fig. 3). At the four grassland sites, LE decreased only modestly. In evergreen needleleaf forests, however, $L E$ decreased by $\sim 33 \%$, with woody savannas intermediate between these two extremes. Sensible heat $(H)$ flux varied less overall with the largest change observed at the woody savanna sites $(\sim 11 \%$ increase). The observed increase in $H$ for evergreen needleleaf forests and woody savannas (Fig. 3) was consistent with temperature $(T)$ increase (mean $\Delta T_{\text {air }}=0.40^{\circ} \mathrm{C}$ and $0.41^{\circ} \mathrm{C}$ respectively for June-September, see Supplementary Table S2). For the grassland sites both $L E$ and $H$ decreased. This decline in available energy was probably linked to the increased albedo of

This article is a U.S. government work, and is not subject to copyright in the United States.

\footnotetext{
${ }^{1}$ School of Earth Science and Environmental Sustainability, Northern Arizona University, Flagstaff, Arizona 86001, USA, ${ }^{2}$ Graduate School of Geography, Clark University, Worcester, Massachusetts 01610, USA, ${ }^{3}$ National Snow and Ice Data Center, Cooperative Institute for Research in Environmental Sciences, University of Colorado at Boulder, Boulder, Colorado 80309, USA, ${ }^{4}$ Department of Environmental Science, Policy and Management, Berkeley, California 94720-3110, USA, ${ }^{5}$ Berkeley Atmospheric Science Center, University of California at Berkeley, Berkeley, California 94720-3110, USA, ${ }^{6}$ Faculty of Land and Food Systems, University of British Columbia, Vancouver, British Columbia V6T 1Z4, Canada, ${ }^{7}$ Department of Civil and Environmental Engineering, University of California at Berkeley, Berkeley, California 94720-3110, USA, ${ }^{8}$ Earth Systems Sciences Division, Oregon State University, Corvallis, Oregon 97330, USA, ${ }^{9}$ Department of Biology, San Diego State University, San Diego, California 92182, USA, ${ }^{10}$ Fondazione Edmund Mach, San Michele all'Adige, (TN) 38010, Italy, ${ }^{11}$ Department of Land, Air, and Water Resources, University of California at Davis, Davis, California 95616, USA,

${ }^{12}$ Southwest Watershed Research Center, USDA-ARS, Tucson, Arizona 85719, USA. *e-mail: christopher.schwalm@nau.edu.
} 

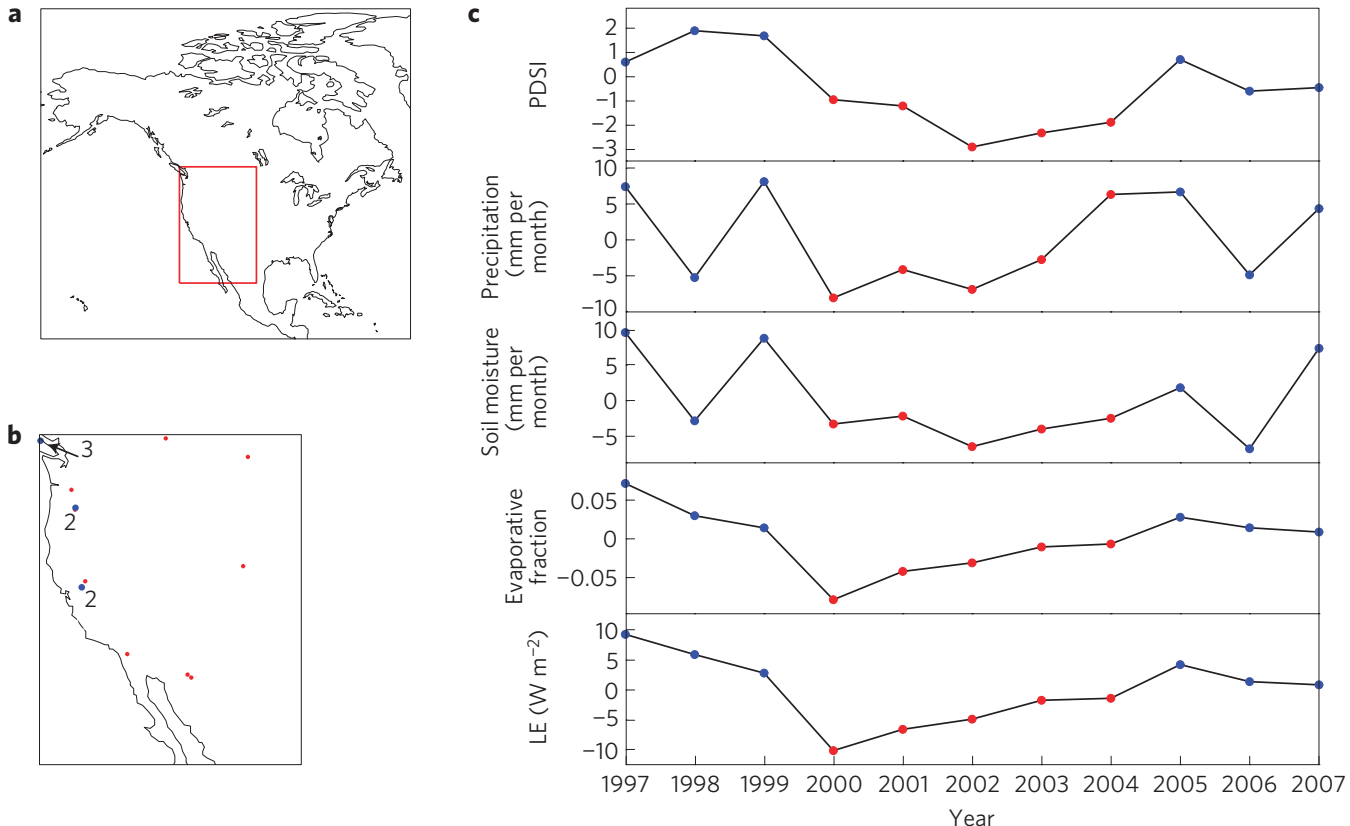

Figure 1 | FLUXNET sites and enviroclimatic indicators. a, North America and spatial domain $\left(25^{\circ}-50^{\circ} \mathrm{N}, 100^{\circ}-125^{\circ} \mathrm{W}\right)$ of the turn of the century drought (red box). b, Location of single FLUXNET sites (red) or numerous sites in close proximity (blue, numbered). c, Area means of instrumental era PDSI, precipitation, soil moisture, evaporative fraction and latent heat (LE) during drought (red) and baseline (blue) years. Values are June-September mean departure from 1997 to 2007. Precipitation uses a water-year basis and PDSI shows drought severity.

water-limited grasslands as senescence and dieback exposed more soil and bright dead-leaf tissue ${ }^{15}$.

Drought effects on water and carbon balances were also clearly evident on the regional scale. Anomalies were recorded for precipitation, soil moisture, instrumental era PDSI, Moderate Resolution Imaging Spectroradiometer (MODIS) GPP, MODIS net primary productivity (NPP) and empirically upscaled FLUXNET data (see Methods). The largest changes were clustered in the Montana and Idaho region of the United States (Supplementary Fig. S2). Relative to the baseline period, area-averaged soil moisture declined from 29 to $25 \mathrm{~mm}$ per month over the full seasonal cycle. The largest reduction of $45 \%$ occurred in climatic summer. Similarly, area-averaged precipitation decreased from 41 to $35 \mathrm{~mm}$ per month, a 15\% reduction (Supplementary Fig. S2). The largest magnitude change in PDSI was - 5.2, a change from slightly wet to severe drought $(1.6$ to -3.6$)$. Over the full domain average PDSI decreased from a near normal value of 0.5 in the baseline period to -1.6 , indicating mild drought ${ }^{16}$, from 2000 to 2004 with $75 \%$ of all grid cells showing at least mild to severe drought and a further $10 \%$ showing incipient drought.

Integrating these effects over the region, we found a sizeable reduction in region-wide productivity and carbon uptake (Supplementary Table S3). GPP showed declines of $-182 \mathrm{TgC} \mathrm{yr}^{-1}\left(-38 \mathrm{~g} \mathrm{C} \mathrm{m}^{-2} \mathrm{yr}^{-1}\right)$ for upscaled FLUXNET and $-234 \mathrm{TgC} \mathrm{yr}^{-1}\left(-47 \mathrm{~g} \mathrm{C} \mathrm{m}^{-2} \mathrm{yr}^{-1}\right)$ for MODIS. Upscaled FLUXNET ecosystem evaporation declined by $-128{\mathrm{Tg} \mathrm{C} \mathrm{yr}^{-1}}^{-1}$ $\left(-27 \mathrm{~g} \mathrm{C} \mathrm{m}^{-2} \mathrm{yr}^{-1}\right)$ and MODIS NPP by $-157 \mathrm{TgC}^{-1}$ $\left(-32 \mathrm{~g} \mathrm{C} \mathrm{m}^{-2} \mathrm{yr}^{-1}\right)$. Changes in MODIS primary productivity were largest in the southeastern portion of the drought area. Upscaled FLUXNET data revealed a similar trend with an additional band of larger negative anomalies (see Methods) in the intermountain region of the United States (Supplementary Fig. S2). Focusing on NEP, upscaled FLUXNET estimates showed enhanced outgassing ranging from -11 to $-29 \mathrm{~g} \mathrm{C} \mathrm{m}^{-2} \mathrm{yr}^{-1}$ (range from two upscaled FLUXNET products, see Methods). This area-integrated effect was less than the observatory response across all towers in western North America $\left(-63 \mathrm{~g} \mathrm{C} \mathrm{m}^{-2} \mathrm{yr}^{-1}\right)$. This highlighted the inherent patchiness of drought ${ }^{11}$ and demonstrated that upscaled products masked pronounced subgrid variability at FLUXNET sites spatially and temporally coincident with the turn of the century drought. Using all three FLUXNET-based estimates of anomaly in conjunction with two estimates based on atmospheric inversions (see Methods) we found that the turn of the century drought elicited a decline in area-integrated terrestrial sink strength (NEP) ranging from -30 to $-298 \mathrm{Tg} \mathrm{Cyr}^{-1}$. This was relative to a baseline sink strength of $177-623 \mathrm{TgC}^{-1}$ (range from two inversions and the network-integrated estimate, see Methods). Thus, the turn of the century drought reduced expected annual net $\mathrm{CO}_{2}$ uptake by, on average, $51 \%$ (full range: $5 \%-168 \%$, see Supplementary Table S3).

A historical record of PDSI reconstructed from tree-ring data for 800-2006 (ref. 7) indicates that the turn of the century drought was the most severe, that is, had the lowest PDSI, fiveyear drought in the past 800 years (Fig. 4). This corresponded to a $-2.64 \sigma$ departure in five-year PDSI over the 1,207-year reconstruction period (Supplementary Fig. S3). Only two drought events of similar severity occurred from 800 to 1200; from 977 to 981 and from 1146 to 1151 . Both were the most severe periods during historical megadroughts ${ }^{17-19}$, barring uncertainties associated with the retention of low-frequency climate variability in these reconstructions. These megadroughts persisted for much longer than the turn of the century drought (77 years for Stine no. 2), but drought severity averaged over the full event was not as extreme $\mathrm{e}^{17,18}$. Furthermore, the geographic extent of these historical North American megadroughts was smaller, with Stine no. 2 limited to California and Nevada. The severity of the turn of century drought was also apparent when restricting our comparison to only a single year as opposed to a mean condition over a five-year time window. Over the past 2,000 years only 97 single-year summer PDSI values were as or more severe than the 2000-2004 drought event.

Precipitation projections (Supplementary Table S4) indicate that the conditions of the turn of the century drought will become the new norm in western North America (Fig. 4). Towards the latter 

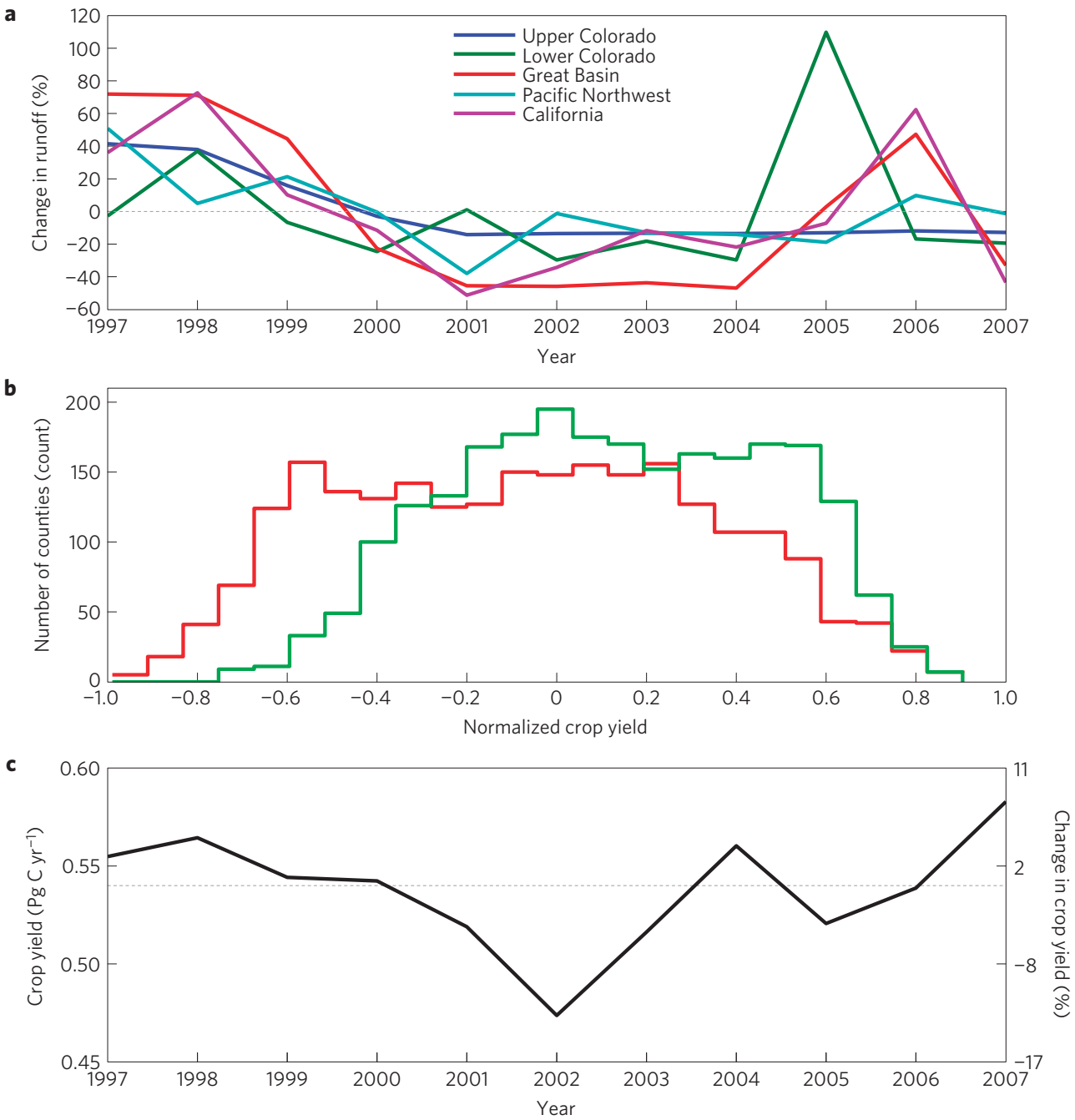

Figure 2 | Basin runoff and crop productivity in the western conterminous United States from 1997 to 2007. a, Annual changes in basin runoff relative to the 11-year mean. Upper Colorado, Lower Colorado, Great Basin, Pacific Northwest, and California basins. b, Detrended normalized crop productivity by county ( $n=2328$ counties in the western United States) during drought (red) and non-drought (green) conditions. Drought peak is shifted towards smaller values (two-sampled two-tailed $t$-test; $p<0.001$ ). c, Total detrended crop productivity and per cent change (solid line) relative to the 11-year mean (dotted line).

half of the twenty-first century the precipitation regime associated with the turn of the century drought will represent an outlier of extreme wetness. Although summer precipitation and summer PDSI are different drought indices, linking PDSI-based hindcasts with precipitation projections is well supported. PDSI is a memory index of precipitation with dependencies on temperature and soil characteristics $^{16}$. Furthermore, focusing on long-term trends we found that the Coupled Model Intercomparison Project phase 5 (CMIP5) precipitation and tree-ring-based PDSI exhibited highly similar frequency distributions (Supplementary Fig. S4) from 1900 to 2006 as did CMIP5 and University of Delaware precipitation from 1901 to 2008 (Supplementary Fig. S5). This distributional similarity indicates that all three drought indices are in good agreement on both the frequency and severity of drought.

This impending drydown of western North America is consistent with present trends in snowpack decline $e^{20,21}$ as well as expected increases in aridity and extreme climate events, including drought ${ }^{22,23}$, and is driven by anthropogenically forced increases in temperature with coincident increases in evapotranspiration and decreases in soil moisture $\mathrm{e}^{24}$. Although regional precipitation patterns are difficult to forecast ${ }^{25}$, climate models tend to underestimate the extent and severity of drought relative to available observations ${ }^{24}$.
As such, actual reductions in precipitation may be greater than shown. Furthermore, the downward trend in precipitation after 2005 in western North America would result in 80 of 95 years, from 2006 to 2100 , with precipitation levels as low as, or lower than, the turn of the century drought. Apart from short-lived pluvials (Fig. 4) forecasted precipitation patterns are consistent with a probable twenty-first century megadrought.

The turn of the century drought in western North America was the most severe drought over the past 800 years, significantly reducing the modest carbon sink normally present in this region. Projections indicate that drought events of this length and severity will be commonplace through the end of the twenty-first century. Even worse, projections suggest that this drought will become the wet end of a drier hydroclimate period in the latter half of the twenty-first century. These drought events, apart from short-lived episodes of abundant precipitation, are projected to persist for most of the present century as the first megadrought of the instrumental era. Decreases in crop productivity, primary production, $L E$, largebasin runoff and $\mathrm{CO}_{2}$ uptake by the land surface associated with the turn of the century drought could become permanent conditions before the end of the century, consistent with a twenty-first century megadrought. 


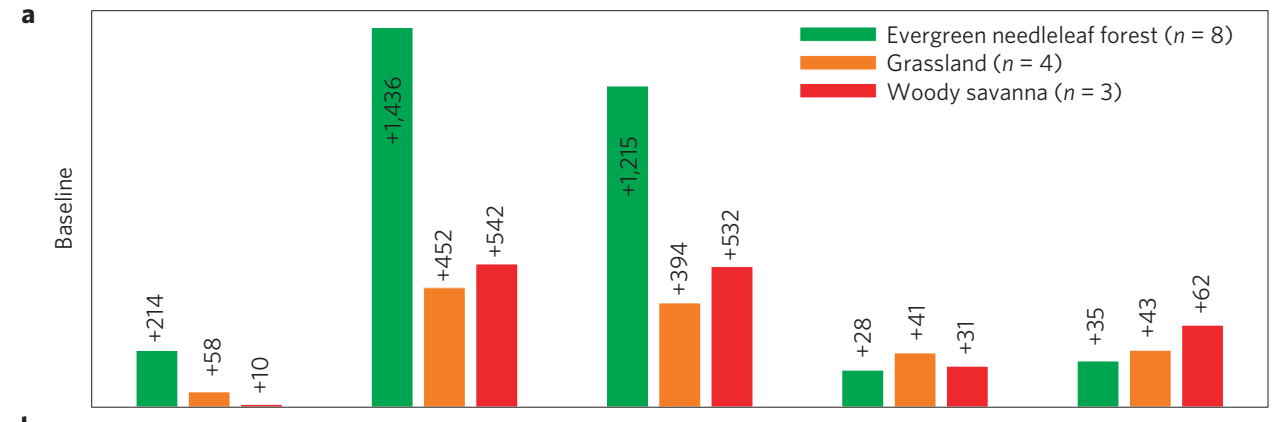

b

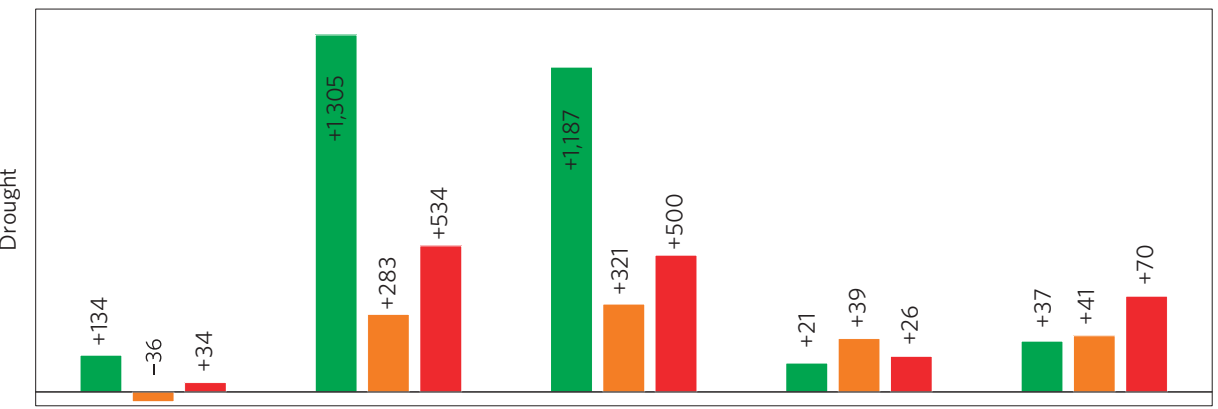

c

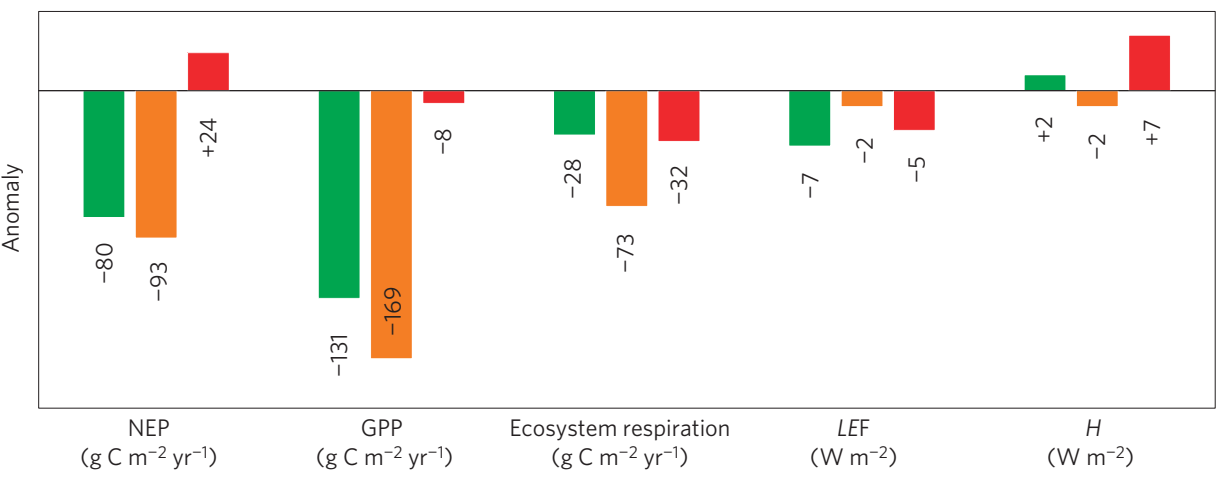

Figure 3 | Carbon and energy fluxes observed at FLUXNET from 1997 to 2007. NEP, GPP, ecosystem respiration, $L E$ and $H$. Values are grouped by land cover and were derived using 15 flux tower locations and 84 site years. a, Baseline. b, Drought. c, Anomaly. Note different scales for carbon and energy fluxes.

\section{Methods}

We quantified monthly changes in enviroclimatic indictors from 1997 to 2007 using the following data sources: PDSI (ref. 26); University of Delaware soil moisture and precipitation (http://climate.geog.udel.edu/ $\sim$ climate); evaporative fraction from the Modern Era Retrospective-analysis for Research and Applications ${ }^{27}$ and Modern Era Retrospective-analysis for Research and Applications LE (ref. 27). For the five main river basins in the western United States, based on region-level hydrologic unit codes, water year basis runoff from 1997 to 2007 was taken from the United States Geological Survey (http://waterwatch.usgs.gov).

Cropland NPP for all counties in the western conterminous United States was taken from yield data collected by the National Agricultural Statistics Service ${ }^{12}$. A positive linear trend in the 1997-2007 record, driven by increased yields as opposed to an increase in area under cultivation ${ }^{28}$, was present in crop NPP. As interannual variation in crop NPP is largely driven by climate ${ }^{28}$ we corrected for the yield-based increases in crop NPP using a detrended time series to focus on climatic variability.

On the footprint scale $\left(1 \mathrm{~km}^{2}\right)$ we used in situ quality-controlled eddy-covariance observations of carbon and energy fluxes at 15 FLUXNET sites (Supplementary Table S1) from the North American Carbon Project Site Synthesis (http://nacp.ornl.gov) and Ameriflux (http://public.ornl.gov/ameriflux) data sets. Sites were included if they were located in western North America $\left(25^{\circ}-50^{\circ} \mathrm{N}, 100^{\circ}-125^{\circ} \mathrm{W}\right)$ and had at least one year of data coverage for both drought and non-drought conditions from 1997 to 2007. For the sites on Vancouver Island the full three-site Douglas-fir-dominated chronosequence was retained; one site was fully in the study domain with the other two within $1 / 3^{\circ}$ of latitude/longitude. Network-integrated fluxes from these in situ locations were derived by integrating an across-site mean value across the full spatial domain of the turn of the century drought.

We complemented our site-specific analysis with spatial fields of carbon exchange for western North America. We used quality-screened MODIS-derived ${ }^{26}$ estimates of annual NPP and GPP. Gridded fields of monthly NEP, GPP and ecosystem respiration were derived by scaling a global compilation of FLUXNET data (www.fluxdata.org) in space and time using model tree ensembles ${ }^{29}$ and ecosystem sensitivities ${ }^{4}$. Both products were forced with different combinations of reanalysis, remote sensing, meteorological and land-cover data. As both perforce excluded other factors that modulate sink strength (for example, lagged effects, disturbance regime, site history, land-use change and soil fertility) they were used only to estimate the anomaly, the absolute difference between drought (2000-2004) and the non-stressed baseline period (1997-1999 and 2005-2007).

In addition to the network-integrated estimate of anomaly, drought and baseline NEP we used two atmospheric inversions, CarbonTracker (http://carbontracker.noaa.gov) and the Jena $\mathrm{CO}_{2}$ inversion (http://www.bgc-jena.mpg.de/bgc-systems), to provide independent estimates of the land sink during the 1997-2007 analysis period (see Supplementary Table S3).

For the 800-2006 period we used summer PDSI reconstructed from a network of dendrochronological records in western North America ${ }^{7}$. We first averaged all grid points in the study domain across the full five-year period to quantify the severity of the turn of the century drought. We then applied this threshold $(-2.11)$ to the full 1,205-year record to estimate the amount of similar events in the past, that is, a similar event matched or exceeded (had a larger negative value) for at least one five-year period.

Precipitation for 1900-2100 was taken from the CMIP5 multimodel ensemble $^{30}$. The 1900-2005 values were based on the historical experiment whereas 2006-2100 values were taken from the RCP8.5 (Representative Concentration Pathways) scenario. We aggregated monthly to peak growing season values (June-August) and then used a five-year mean value to quantify the severity of the turn of the century drought.

Data were analysed as mean values for the drought (2000-2004), baseline (1997-1999 and 2005-2007) and anomalies: $\Delta x=x_{\text {drought }}-x_{\text {baseline }}=\bar{x}_{2000-2004}-\bar{x}_{1997-1999,2005-2007}$, where $x$ indicates a 

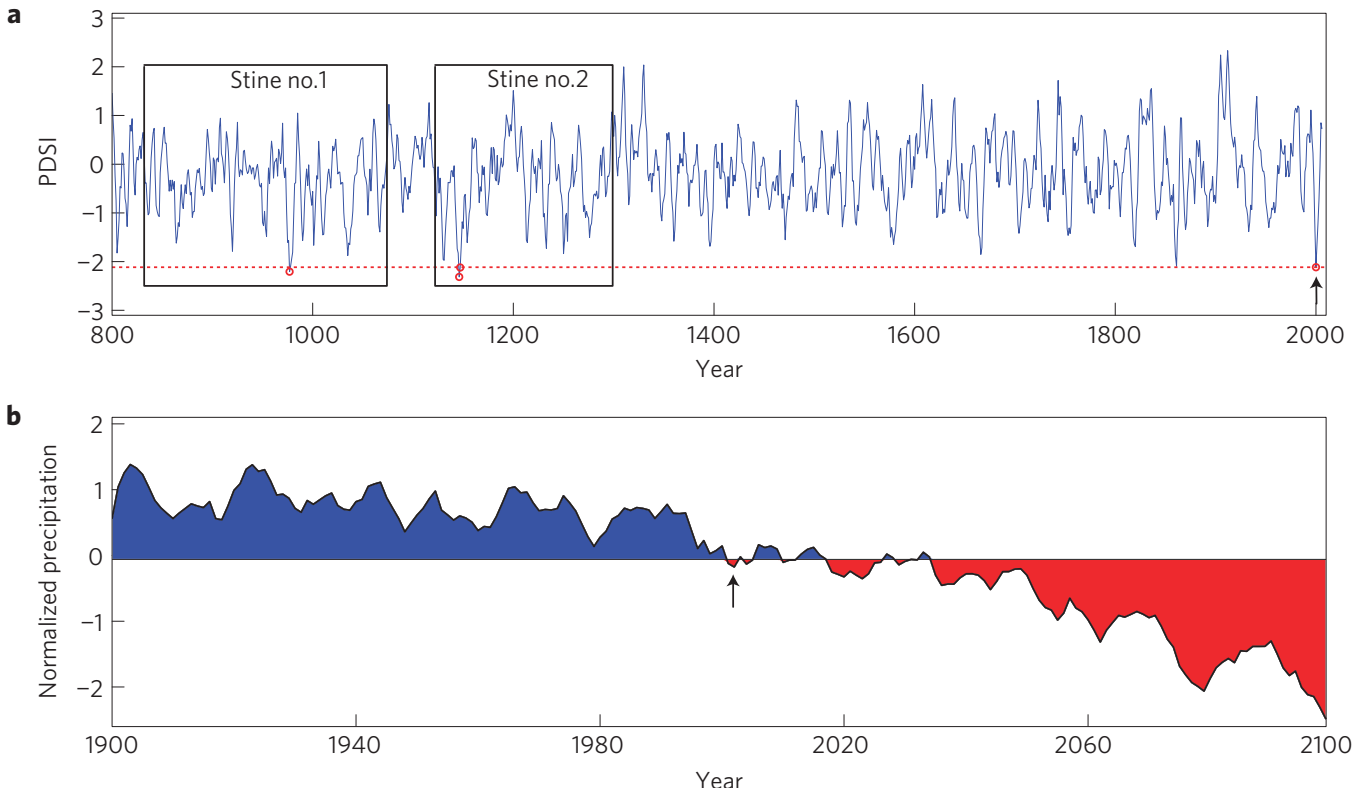

Figure 4 | Drought over western North America from $\mathbf{8 0 0}$ to 2100. a, Reconstructed summer PDSI from 800 to 2006, five-year mean. Black rectangles show Stine no. 1 and Stine no. 2 megadroughts. Red circles denote five-year drought events as severe as the turn of the century event. Red line denotes the mean PDSI during the 2000-2004 event (-2.11). b. Normalized CMIP5 summer precipitation from 1900 to 2100, five-year mean. Horizontal line denotes the turn of the century drought severity. Red and blue shading shows dryness more or less severe, respectively, than the turn of the century drought. Arrows indicate the turn of the century drought.

given data field and the overbar averaging across the range of available data from the subscripted years. Apart from tree-ring-based PDSI and precipitation, data outside of the 11-year analysis window were not considered.

Received 27 February 2012; accepted 25 June 2012; published online 29 July 2012

\section{References}

1. Nemani, R. R. et al. Recent trends in hydrological balance have enhanced the terrestrial carbon sink in the United States. Geophys. Res. Lett. 29, 1468 (2002).

2. Potter, C. S. et al. Estimating carbon budgets for US ecosystems. Eos 87, 85-96 (2006).

3. Xiao, J. et al. Assessing net ecosystem carbon exchange of US terrestrial ecosystems by integrating eddy covariance flux measurements and satellite observations. Agric. For. Meteorol. 151, 60-69 (2011).

4. Schwalm, C. R., Williams, C. A. \& Schaefer, K. M. Carbon consequences of global hydrologic change, 1948-2009. J. Geophys. Res. 116, G03042 (2011).

5. Bates, B. C., Kundzewicz, Z. W., Wu, S. \& Palutikof, J. P. (eds) Climate Change and Water. Technical Paper of the Intergovernmental Panel on Climate Change (IPCC Secretariat, 2008).

6. Huntington, T. G. Evidence for intensification of the global water cycle: Review and synthesis. J. Hydrol. 319, 83-95 (2006).

7. Cook, E. R., Woodhouse, C. A., Eakin, C. M., Meko, D. M. \& Stahle, D. W. Long term aridity changes in the western United States. Science 306, 1015-1018 (2004).

8. Dai, A., Trenberth, K. E. \& Qian, T. A global data set of Palmer Drought Severity Index for 1870-2002: Relationship with soil moisture and effects of surface warming. J. Hydrometerol. 5, 1117-1130 (2004).

9. Lobell, D. B. et al. Satellite estimates of productivity and light use efficiency in United States agriculture, 1982-1998. Glob. Change Biol. 8, 1-15 (2002).

10. Misson, L., Tang, J., Xu, M., McKay, M. \& Goldstein, A. Influences of recovery from clear-cut, climate variability, and thinning on the carbon balance of a young ponderosa pine plantation. Agric. For. Meteorol. 130, 207-222 (2005).

11. Breshears, D. D., López-Hoffman, L. \& Graumlich, L. J. When ecosystem services crash: preparing for big, fast, patchy climate change. Ambio 40, 256-263 (2011).

12. Schwalm, C. R. et al. Assimilation exceeds respiration sensitivity to drought: A FLUXNET synthesis. Glob. Change Biol. 16, 657-670 (2010).

13. Hibbard, K. A., Law, B. E., Reichstein, M. \& Sulzman, J. An analysis of soil respiration across northern hemisphere temperate ecosystems. Biogeochemistry 73, 29-70 (2005).

14. Scott, R. L., Huxman, T. E., Williams, D. \& Goodrich, D. C. Ecohydrological impacts of woody-plant encroachment: Seasonal patterns of water and carbon dioxide exchange within a semiarid riparian environment. Glob. Change Biol. 12, 311-324 (2006)
15. Wang, S. \& Davidson, A. Impact of climate variations on surface albedo of a temperate grassland. Agr. Forest Meteorol. 142, 133-142 (2007).

16. Alley, W. M. Palmer drought severity index: Limitations and assumptions. J. Clim. Appl. Meteorol. 23, 1100-1109 (1984).

17. Cook, E. R. et al. Megadroughts in North America: placing IPCC projections of hydroclimatic change in a long-term palaeoclimate context. J. Quat. Sci. 25, 48-61 (2010).

18. Woodhouse, C. A., Meko, D. M., MacDonald, G. M., Stahle, D. W. \& Cook, E. R. A 1,200-year perspective of 21st century drought in southwestern North America. Proc. Natl Acad. Sci. USA 107, 21283-21288 (2010).

19. Stahle, D. W., Fye, F. K., Cook, E. R. \& Griffin, R. D. Tree-ring reconstructed megadroughts over North America since AD 1300. Climatic Change 83, 133-149 (2007).

20. Mote, P. W., Hamlet, A. F., Clark, M. P. \& Lettenmaier, D. P. Declining mountain snowpack in western North America. Bull. Am. Meteorol. Soc. 86, 39-49 (2005).

21. Pederson, G. T. et al. The unusual nature of recent snowpack declines in the North American Cordillera. Science 333, 332-335 (2011).

22. Seager, R. et al. Model projections of an imminent transition to a more arid climate in southwestern North America. Science 316, 1181-1184 (2007).

23. Burke, E. J., Brown, S. J. \& Christidis, N. Modeling the recent evolution of global drought and projections for the twenty-first century with the Hadley centre climate model. J. Hydrometeorol. 7, 1113-1125 (2006).

24. Wehner, M. F. et al. Projections of future drought in the Continental United States and Mexico. J. Hydrometeorol. 12, 1359-1377 (2011).

25. Meehl, G. A. et al. The WCRP CMIP3 multi-model dataset: A new era in climate change research. Bull. Amer. Meteorol. Soc. 88, 1383-1394 (2007).

26. Zhao, M. \& Running, S. W. Drought-Induced reduction in global terrestrial net primary production from 2000 through 2009. Science 329, 940-943 (2010).

27. Bosilovich, M., Chen, J., Robertson, F. R. \& Adler, Evaluation of global precipitation in reanalyses. J. Appl. Meteorol. Climatol. 47, 2279-2299 (2008).

28. Hicke, J. A., Lobell, D. B. \& Asner, G. P. Cropland area and net primary production computed from 30 Years of USDA agricultural harvest data. Earth Interact. 8, 1-20 (2004).

29. Jung, M. et al. Global patterns of land-atmosphere fluxes of carbon dioxide, latent heat, and sensible heat derived from eddy covariance, satellite, and meteorological observations. J. Geophys. Res. 116, G00J07 (2011).

30. Taylor, K. E., Stouffer, R. J. \& Meehl, G. A. An overview of CMIP5 and the experiment design. Bull. Amer. Meteorol. Soc. 90, 1467-1485 (2011).

\section{Acknowledgements}

C.R.S., C.A.W. and K.S. were supported by the US National Science Foundation grant ATM-0910766. C.A.W. was additionally supported through NASA Terrestrial 
Ecology award NNX10AR68G (2N041). B.E.L. was supported by AmeriFlux (the Office of Science (BER), US Department of Energy (DE-FG02-04ER63917 and DE-FG02-04ER63911)). K.T.P.U. was supported by the US National Science Foundation grant F1137306/MIT subaward 5710003122 to the University of California, Davis. We acknowledge the World Climate Research Programme's Working Group on Coupled Modelling, which is responsible for CMIP, and we thank the climate modelling groups (Supplementary Table S4) for producing and making available their model output. For CMIP the US Department of Energy's Program for Climate Model Diagnosis and Intercomparison provided coordinating support and led development of software infrastructure in partnership with the Global Organization for Earth System Science Portals. CarbonTracker 2011 results provided by NOAA ESRL, Boulder, Colorado, USA from the website at http://carbontracker.noaa.gov. Jena $\mathrm{CO}_{2}$ inversion results provided courtesy of C. Rödenbeck, Max Planck Institute for Biogeochemistry, Jena, Germany.

\section{Author contributions}

C.R.S., C.A.W. and K.S. designed the study and are responsible for the integrity of the manuscript; C.R.S. carried out the analysis and all calculations. C.R.S., with C.A.W. and K.S., wrote the manuscript. D.B., T.A.B., A.H.G., B.E.L., W.C.O., K.T.P.U. and R.L.S. contributed FLUXNET data. All authors discussed and commented on the manuscript.

\section{Additional information}

Supplementary information is available in the online version of the paper. Reprints and permissions information is available online at www.nature.com/reprints. Correspondence and requests for materials should be addressed to C.R.S.

\section{Competing financial interests}

The authors declare no competing financial interests. 
Supplementary Table 1. FLUXNET site characteristics.

\begin{tabular}{|c|c|c|c|c|}
\hline Site Code & Available Data & Land Cover & Latitude & Longitude \\
\hline $\mathrm{CA}-\mathrm{Ca} 1^{31}$ & $1998-2006$ & ENF & 49.87 & -125.33 \\
\hline $\mathrm{CA}-\mathrm{Ca} 2^{31}$ & 2001-2006 & ENF & 49.87 & -125.29 \\
\hline $\mathrm{CA}-\mathrm{Ca} 3^{31}$ & 2002-2006 & ENF & 49.53 & -124.90 \\
\hline CA-Let ${ }^{32}$ & 2000-2007 & GRA & 49.71 & -112.94 \\
\hline US-Aud & 2002-2006 & GRA & 31.59 & -110.51 \\
\hline US-Blo ${ }^{33}$ & 1999-2006 & ENF & 38.89 & -120.63 \\
\hline US-FPe ${ }^{34}$ & 2000-2006 & GRA & 48.31 & -105.10 \\
\hline US-Me $2^{35}$ & $2002,2004-2007$ & ENF & 44.45 & -121.56 \\
\hline US-Me $3^{36}$ & 2004-2005 & ENF & 44.31 & -121.61 \\
\hline US-NR $1^{37}$ & $2000-2007$ & ENF & 40.03 & -105.55 \\
\hline US-SO $2^{38}$ & $2000,2005-2006$ & WSA & 33.37 & -116.62 \\
\hline US-SRM $^{39}$ & 2004-2006 & WSA & 31.82 & -110.86 \\
\hline US-Ton ${ }^{40}$ & 2002-2007 & WSA & 38.43 & -120.97 \\
\hline US-Var ${ }^{40}$ & 2001-2007 & GRA & 38.41 & -120.95 \\
\hline US-Wrc ${ }^{41}$ & 1998-2006 & ENF & 45.82 & -121.95 \\
\hline
\end{tabular}

Land cover follows the IGBP classification $^{42}$ : ENF, evergreen needleleaf forest; GRA, grassland; WSA, woody savanna. 
Supplementary Table 2. Observed in situ climate, carbon and energy fluxes at FLUXNET locations.

\begin{tabular}{|c|c|c|c|c|c|c|c|c|c|c|c|c|c|c|c|c|c|c|c|c|c|c|}
\hline \multirow[b]{3}{*}{ Site Code } & \multicolumn{12}{|c|}{ Anomaly } & \multirow{2}{*}{\multicolumn{5}{|c|}{ Drought }} & \multirow{2}{*}{\multicolumn{5}{|c|}{ Baseline }} \\
\hline & \multicolumn{7}{|c|}{ June-to-September } & \multicolumn{5}{|c|}{ Annual } & & & & & & & & & & \\
\hline & $\triangle N E P$ & $\triangle \mathrm{GPP}$ & $\Delta R e$ & $\Delta \boldsymbol{P}$ & $\Delta \boldsymbol{T}_{\text {air }}$ & $\Delta L E$ & $\Delta \boldsymbol{H}$ & $\triangle N E P$ & $\triangle G P P$ & $\Delta R e$ & $\Delta L E$ & $\Delta \boldsymbol{H}$ & $N E P$ & GPP & $R e$ & $L E$ & $H$ & $N E P$ & GPP & Re & $L E$ & $\boldsymbol{H}$ \\
\hline CA-Ca1 & -4 & -4 & 0 & 0 & -0.02 & 1 & -11 & -50 & -33 & 17 & - & 0 & 221 & 2294 & 2072 & - & 19 & 272 & 2327 & 2055 & - & 20 \\
\hline $\mathrm{CA}-\mathrm{Ca} 2$ & -22 & -73 & -50 & 11 & 0.28 & -1 & 2 & -148 & -390 & -241 & - & - & -621 & 575 & 1196 & 21 & 25 & -472 & 965 & 1438 & - & - \\
\hline CA-Ca3 & -11 & -40 & -29 & -3 & 1.12 & - & 2 & -133 & -322 & -189 & - & - & -144 & 1389 & 1534 & - & - & -11 & 1712 & 1723 & - & - \\
\hline CA-Let & -6 & -2 & 4 & -9 & 0.28 & -18 & 14 & -8 & 15 & 24 & - & - & 129 & 524 & 395 & - & - & 138 & 509 & 371 & - & - \\
\hline US-Aud & -65 & -78 & -13 & -41 & 0.39 & -13 & 14 & -349 & -406 & -57 & -4 & 3 & -201 & -88 & 112 & 20 & 51 & 148 & 318 & 169 & 24 & 47 \\
\hline US-Blo & -34 & -29 & 5 & -6 & 0.79 & -19 & 10 & -227 & -279 & -51 & -12 & 7 & 502 & 1086 & 586 & 50 & 46 & 730 & 1366 & 638 & 63 & 39 \\
\hline US-FPe & 8 & 3 & -6 & -1 & -0.37 & -20 & -19 & -29 & -85 & -41 & -9 & -9 & -69 & 158 & 243 & 21 & 25 & -40 & 243 & 284 & 31 & 35 \\
\hline US-Me2 & 1 & 28 & 27 & -4 & 0.19 & 6 & -8 & -24 & 142 & 166 & 0 & 5 & 487 & 1469 & 981 & 37 & 41 & 511 & 1326 & 815 & 37 & 35 \\
\hline US-Me3 & 3 & - & - & 14 & 0.71 & 1 & -9 & 81 & - & - & -2 & -1 & 238 & 857 & 618 & 24 & 37 & 157 & - & - & 26 & 38 \\
\hline US-NR1 & -6 & -25 & -19 & 5 & 0.51 & -1 & 4 & -29 & -112 & -82 & 1 & 2 & 22 & 663 & 640 & 45 & 43 & 52 & 775 & 722 & 43 & 41 \\
\hline US-SO2 & 16 & -1 & -18 & -12 & 0.84 & -21 & 9 & 33 & 87 & 54 & -9 & 7 & 75 & 514 & 439 & 27 & 82 & 41 & 426 & 384 & 36 & 74 \\
\hline US-SRM & -2 & -16 & -14 & -21 & -0.05 & -13 & 11 & 8 & -50 & -59 & -2 & 0 & -57 & 206 & 264 & 22 & 63 & -66 & 257 & 323 & 24 & 63 \\
\hline US-Ton & 0 & -6 & -6 & -1 & 0.43 & -10 & 22 & 29 & -61 & -91 & -2 & 12 & 82 & 879 & 796 & 29 & 62 & 53 & 940 & 887 & 32 & 49 \\
\hline US-Var & 1 & -4 & -6 & 0 & 0.38 & -7 & -6 & 14 & -198 & -218 & -5 & 0 & -1 & 537 & 533 & 21 & 45 & -15 & 736 & 752 & 27 & 45 \\
\hline US-Wrc & -6 & 31 & 36 & 33 & -0.42 & 5 & -6 & -109 & 76 & 184 & 2 & -1 & 362 & 1656 & 1293 & 36 & 36 & 471 & 1579 & 1109 & 34 & 37 \\
\hline Mean & -8 & -15 & -6 & -2 & 0.34 & -8 & 2 & -63 & -116 & -42 & -4 & 2 & 68 & 847 & 780 & 29 & 44 & 131 & 962 & 833 & 34 & 43 \\
\hline Lower & -24 & -34 & -17 & -10 & 0.12 & -14 & -1 & -139 & -204 & -101 & -6 & 0 & -90 & 582 & 563 & 24 & 35 & 11 & 683 & 594 & 29 & 37 \\
\hline Upper & -2 & -2 & 5 & 5 & 0.55 & -4 & 22 & -20 & -31 & 25 & -1 & 5 & 189 & 1233 & 1096 & 36 & 55 & 279 & 1295 & 1149 & 44 & 52 \\
\hline
\end{tabular}

Anomaly shows the difference between drought (2000 to 2004) and non-drought baseline condition (1995 to $1997 \& 2005$ to 2007 ): $\Delta x=\bar{x}_{2000-2004}-\bar{x}_{1997-1999,2005-2007}$, where $x$ is a single data field averaged across all available data from the subscripted years. June-toSeptember units are $\mathrm{g} \mathrm{C} \mathrm{m}^{-2}$ month $^{-1}$ for carbon balance terms, mean monthly $\mathrm{W} \mathrm{m}^{-2}$ for latent heat $(L E)$ and sensible heat $(H)$, mm $\mathrm{mon}^{-1}$ for precipitation $(P)$ and ${ }^{\circ} \mathrm{K}$ for air temperature $\left(T_{\text {air }}\right)$. Annual values have units $\mathrm{g} \mathrm{C} \mathrm{m}^{-2} \mathrm{yr}^{-1}$ for carbon balance terms and $\mathrm{W} \mathrm{m}^{-2}$ (monthly averages) for $L E$ and $H$. Carbon balance is not closed in some cases due to rounding or missing data. Mean was calculated across all non-missing site values. Lower and upper confidence bounds (95\%) were derived using a bias-corrected bootstrap with 1000 bootstrap samples. 
Supplementary Table 3. Turn of the century drought carbon balance terms.

\begin{tabular}{|c|c|c|c|c|c|}
\hline Carbon Balance Term & Available Data & Anomaly & Drought & Baseline & Reduction (\%) \\
\hline Cropland $N P P^{12}$ & $1997-2007$ & -29 & 522 & 551 & 5.2 \\
\hline MODIS $G P P^{26}$ & 2000-2007 & -234 & 2,191 & 2,424 & 9.7 \\
\hline MODIS NPP 26 & $2000-2007$ & -157 & 1,211 & 1,367 & 11.5 \\
\hline Upscaled FLUXNET $G P P^{29}$ & 1997-2007 & -182 & 2,166 & 2,348 & 7.8 \\
\hline Upscaled FLUXNET $R e^{29}$ & $1997-2007$ & -128 & - & - & - \\
\hline Upscaled FLUXNET $N E P^{29}$ & $1997-2007$ & -55 & - & - & $16.8^{*}$ \\
\hline Upscaled FLUXNET $N E P^{4}$ & $1997-2007$ & -136 & - & - & $41.5^{*}$ \\
\hline Network-integrated FLUXNET & See Supplementary & -298 & 325 & 623 & 47.8 \\
\hline$N E P$ (this study) & Table 1 & & & & \\
\hline CarbonTracker $N E P^{43}$ & 2000-2007 & -30 & 147 & 177 & 16.9 \\
\hline Jena $N E P^{44}$ & 1997-2007 & -83 & 101 & 188 & 44.1 \\
\hline Smallest $N E P$ reduction & - & -30 & - & 623 & 4.8 \\
\hline Mean $N E P$ reduction & - & - & - & - & 51.0 \\
\hline Median $N E P$ reduction & - & - & - & - & 37.6 \\
\hline Largest $N E P$ reduction & - & -298 & - & 177 & 168.4 \\
\hline
\end{tabular}

Anomaly shows the annual difference between drought (2000 to 2004) and non-drought

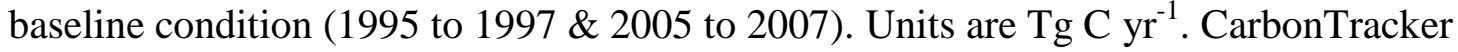
output (native resolution: $1^{\circ}$ x $1^{\circ}$ ) was taken from the 2011 release. Jena inversion output (native resolution: $3.75^{\circ} \times 5^{\circ}$ ) from run ID s96_v3.3_monthly was regridded to $1^{\circ}$ grid before estimating land sink values for the turn for the century drought. For both inversions only the biospheric land flux was used (fire emissions and fossil fuels were excluded). Reduction shows the percentage decline (anomaly over baseline). Asterisked (*) values were calculated using the mean baseline value from the network-integrated FLUXNET NEP estimate and the two inversion NEP estimates. Upscaled estimates of $N E P$ and $R e$ were not used for the drought or baseline as these excluded other factors that modulate sink strength (e.g., lagged effects, disturbance regime, site history, land use change, and soil fertility). Largest and smallest reduction show, based on all estimates of anomaly and baseline, the lowest and highest percentage reductions in land sink. Mean (median) NEP reduction shows the mean (median) across all possible estimates of reduction ( $n=15$ from 5 anomaly values $x 3$ baseline values). 
Supplementary Table 4. CMIP5 models used to estimate 1900 to 2099 precipitation.

\begin{tabular}{|c|c|c|}
\hline Modeling Center/Group & Institute ID & IPCC Model Name \\
\hline Beijing Climate Center, China Meteorological Administration & $\mathrm{BCC}$ & BCC-CSM1.1 \\
\hline Canadian Centre for Climate Modelling and Analysis & ССCMA & CanESM2 \\
\hline National Center for Atmospheric Research & NCAR & CCSM 4 \\
\hline $\begin{array}{l}\text { Centre National de Recherches Meteorologiques / Centre Europeen de } \\
\text { Recherche et Formation Avancees en Calcul Scientifique }\end{array}$ & CNRM-CERFACS & CNRM-CM5 \\
\hline $\begin{array}{l}\text { Commonwealth Scientific and Industrial Research Organization in } \\
\text { collaboration with Queensland Climate Change Centre of Excellence }\end{array}$ & CSIRO-QCCCE & CSIRO-Mk3.6 \\
\hline EC-EARTH consortium & EC-EARTH & EC-EARTH \\
\hline \multirow{3}{*}{ NOAA Geophysical Fluid Dynamics Laboratory } & \multirow{3}{*}{ NOAA GFDL } & GFDL-CM3 \\
\hline & & GFDL-ESM2G \\
\hline & & GFDL-ESM2M \\
\hline \multirow{2}{*}{ NASA Goddard Institute for Space Studies } & \multirow{2}{*}{ NASA GISS } & GISS-E2-H \\
\hline & & GISS-E2-R \\
\hline \multirow{2}{*}{ Met Office Hadley Centre } & \multirow{2}{*}{$\mathrm{MOHC}$} & HadGEM2-CC \\
\hline & & HadGEM2-ES \\
\hline Institute for Numerical Mathematics & INM & INM-CM4 \\
\hline \multirow{2}{*}{ Institut Pierre-Simon Laplace } & \multirow{2}{*}{ IPSL } & IPSL-CM5A-LR \\
\hline & & IPSL-CM5A-MR \\
\hline \multirow{2}{*}{$\begin{array}{l}\text { Japan Agency for Marine-Earth Science and Technology, Atmosphere and } \\
\text { Ocean Research Institute (The University of Tokyo), and National Institute } \\
\text { for Environmental Studies }\end{array}$} & \multirow{2}{*}{ MIROC } & MIROC-ESM-CHEM \\
\hline & & MIROC-ESM \\
\hline $\begin{array}{l}\text { Atmosphere and Ocean Research Institute (The University of Tokyo), } \\
\text { National Institute for Environmental Studies, and Japan Agency for Marine- } \\
\text { Earth Science and Technology }\end{array}$ & MIROC & MIROC5 \\
\hline Max Planck Institute for Meteorology & MPI-M & MPI-ESM-LR \\
\hline Meteorological Research Institute & MRI & MRI-CGCM3 \\
\hline Norwegian Climate Centre & $\mathrm{NCC}$ & NorESM1-M \\
\hline
\end{tabular}




\section{Supplementary Figure 1.}
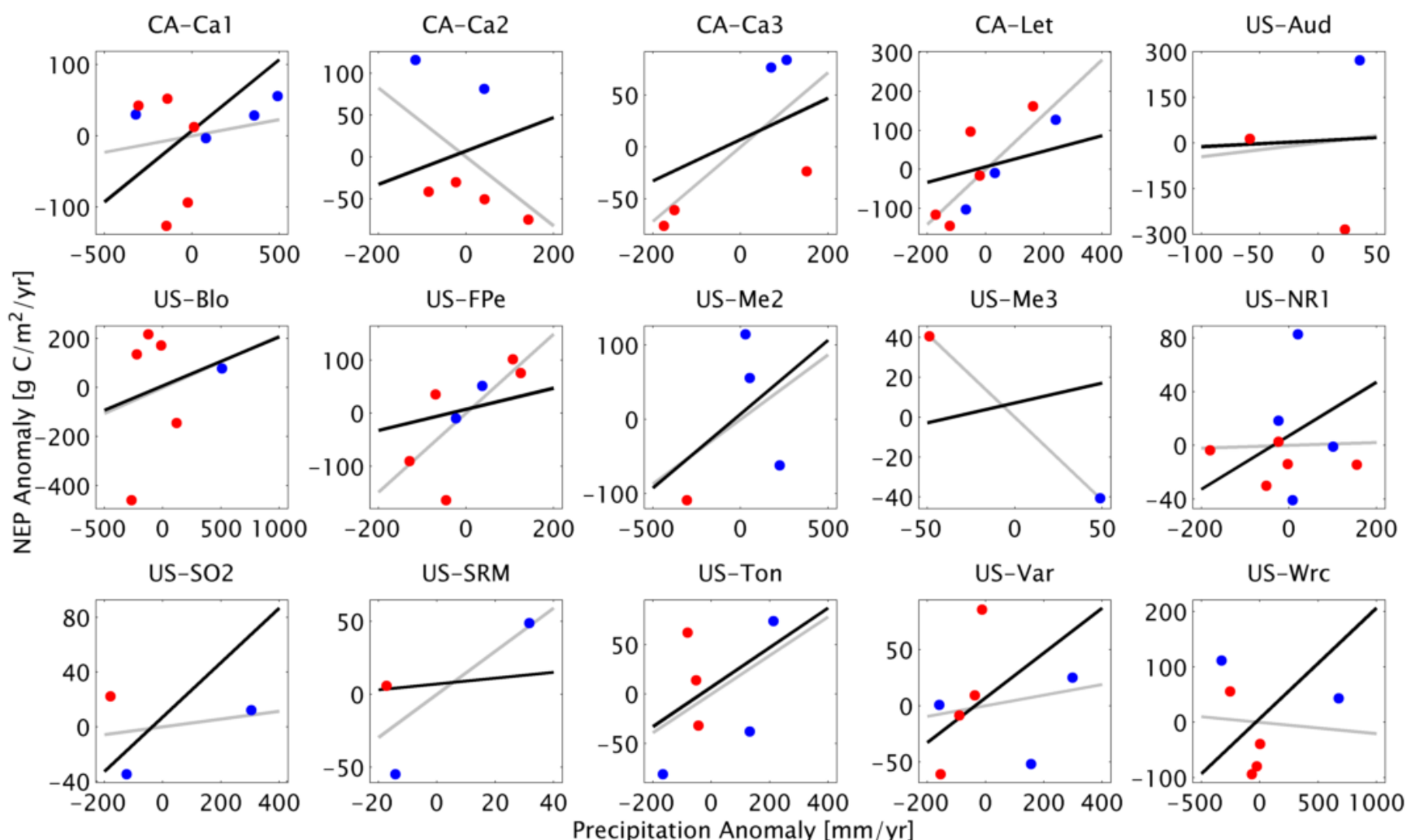

Supplementary Figure 1. FLUXNET as an integrated observatory. Panels show site-specific annual anomalies of net ecosystem productivity (NEP) and precipitation. Anomalies were calculated as the departure from the 1997-2007 mean annual integral, i.e., included the 5-yr (2000-2004, red circles) region-wide drought event and a 6-yr (1997-1999 and 2005-2007, blue circles) region-wide non-drought reference period. Grey lines in each panel are site-specific slopes. The black line shows the composite slope when all sitespecific data are aggregated to represent the region-wide drought and non-drought baseline conditions $(p=0.037 ; n=30$ from 15 sites $x 2$ conditions). 12 of 15 sites exhibit the same sign as the composite slope. The aggregate response across all sites (black line) demonstrates a coherent signal despite noteworthy heterogeneity in response at the site level. 


\section{Supplementary Figure 2.}
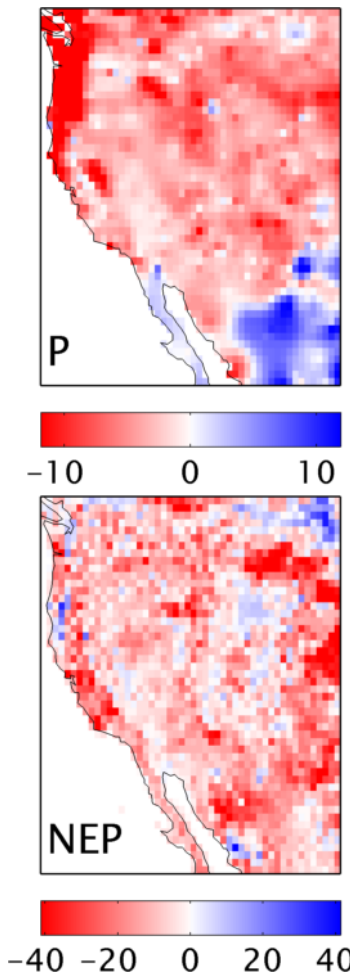
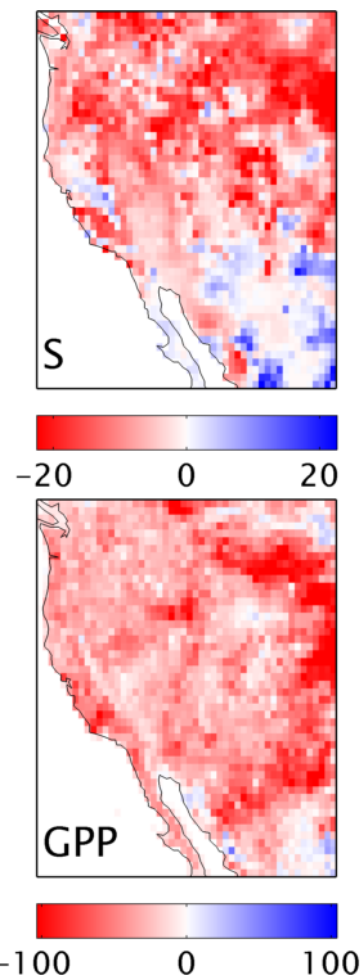
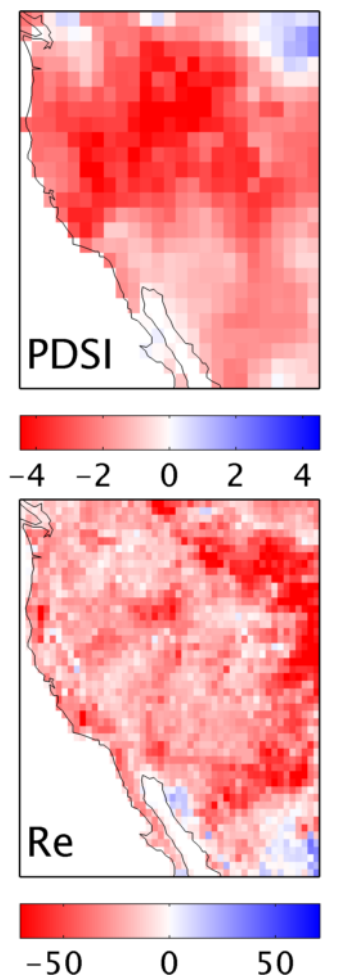
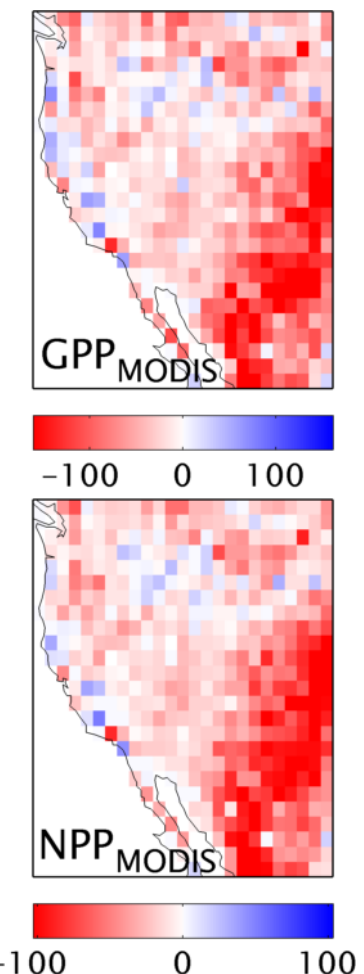

Supplementary Figure 2. Gridded contrasts of carbon flux and enviroclimatic indicators in western North America. Maps show the pixel-by-pixel differences between drought and baseline conditions: $\Delta x=\bar{x}_{2000-2004}-\bar{x}_{1997-19992005-2007}$, where $x$ is a single data field averaged across the subscripted years. Carbon fluxes are net ecosystem productivity $(N E P)$, gross primary productivity (GPP), and ecosystem respiration $(R e)$ from model tree ensemble-scaled eddy covariance data ${ }^{29}$ as well as GPP (GPP MODIS $)$ and net primary productivity $\left(N P P_{\text {MODIS }}\right)$ from MODIS ${ }^{26}$. All carbon fluxes have units $\mathrm{g} \mathrm{C} \mathrm{m}^{-2} \mathrm{yr}^{-1}$. Enviroclimatic indicators are UDel precipitation $(P$, $\mathrm{mm}$ month $^{-1}$, http://climate.geog.udel.edu/ climate), UDel soil moisture (S, mm month ${ }^{-1}$, http://climate.geog.udel.edu/ climate) and instrumental era Palmer Drought Severity Index ${ }^{26}$ (PDSI, dim). Red indicates a drying down of the biosphere, less terrestrial $\mathrm{CO}_{2}$ uptake, and smaller gross fluxes. Note scale changes. 


\section{Supplementary Figure 3.}

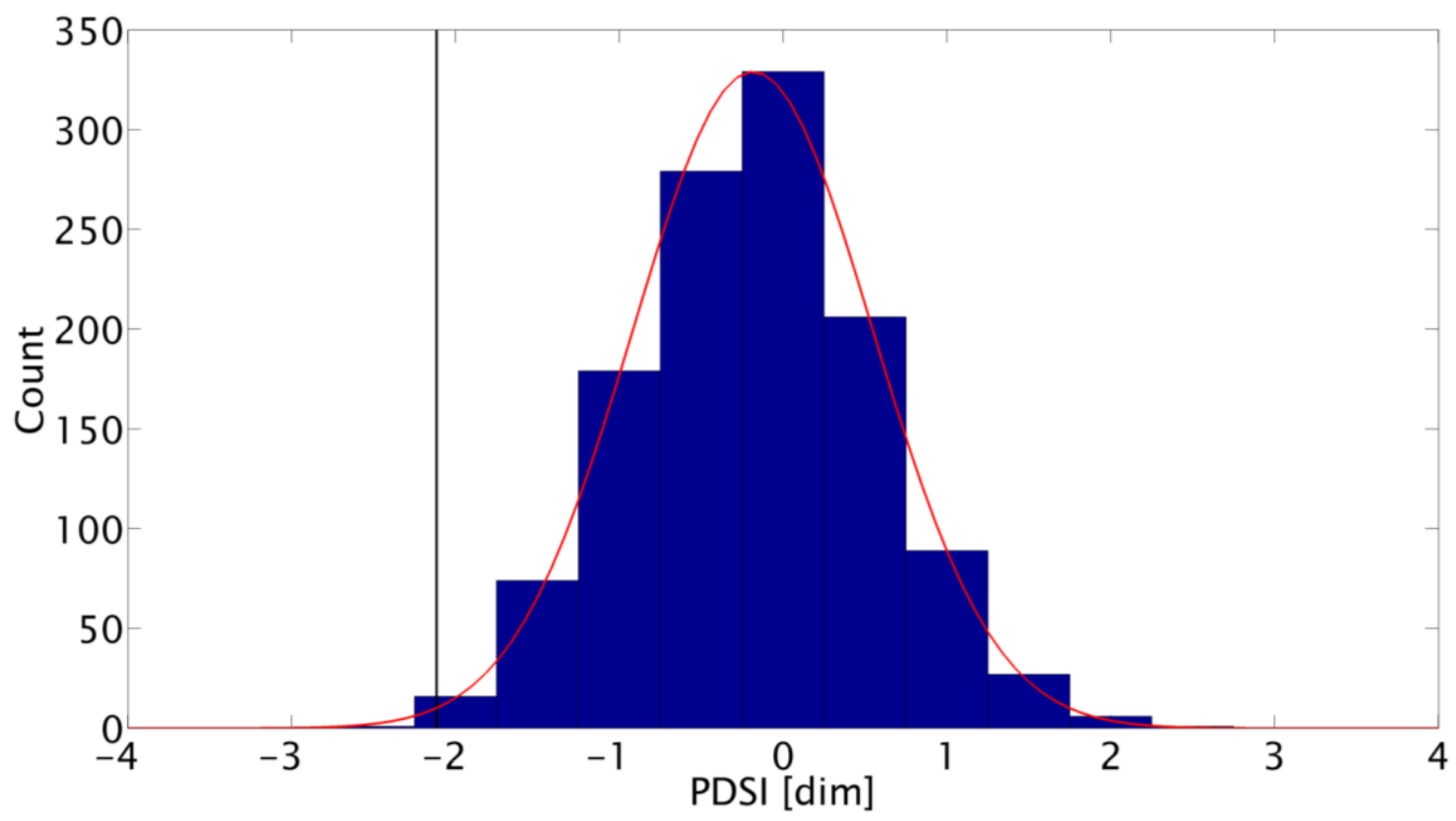

Supplementary Figure 3. Histogram of reconstructed 5-yr average summer $\operatorname{PDSI}^{7}$ (dim) from 800 to 2006 CE. Red curve is Gaussian density. Vertical line indicates turn of the century drought (= -2.11); a $-2.64 \sigma$ departure in 5-yr PDSI over the 1207-yr reconstruction period. 


\section{Supplementary Figure 4.}
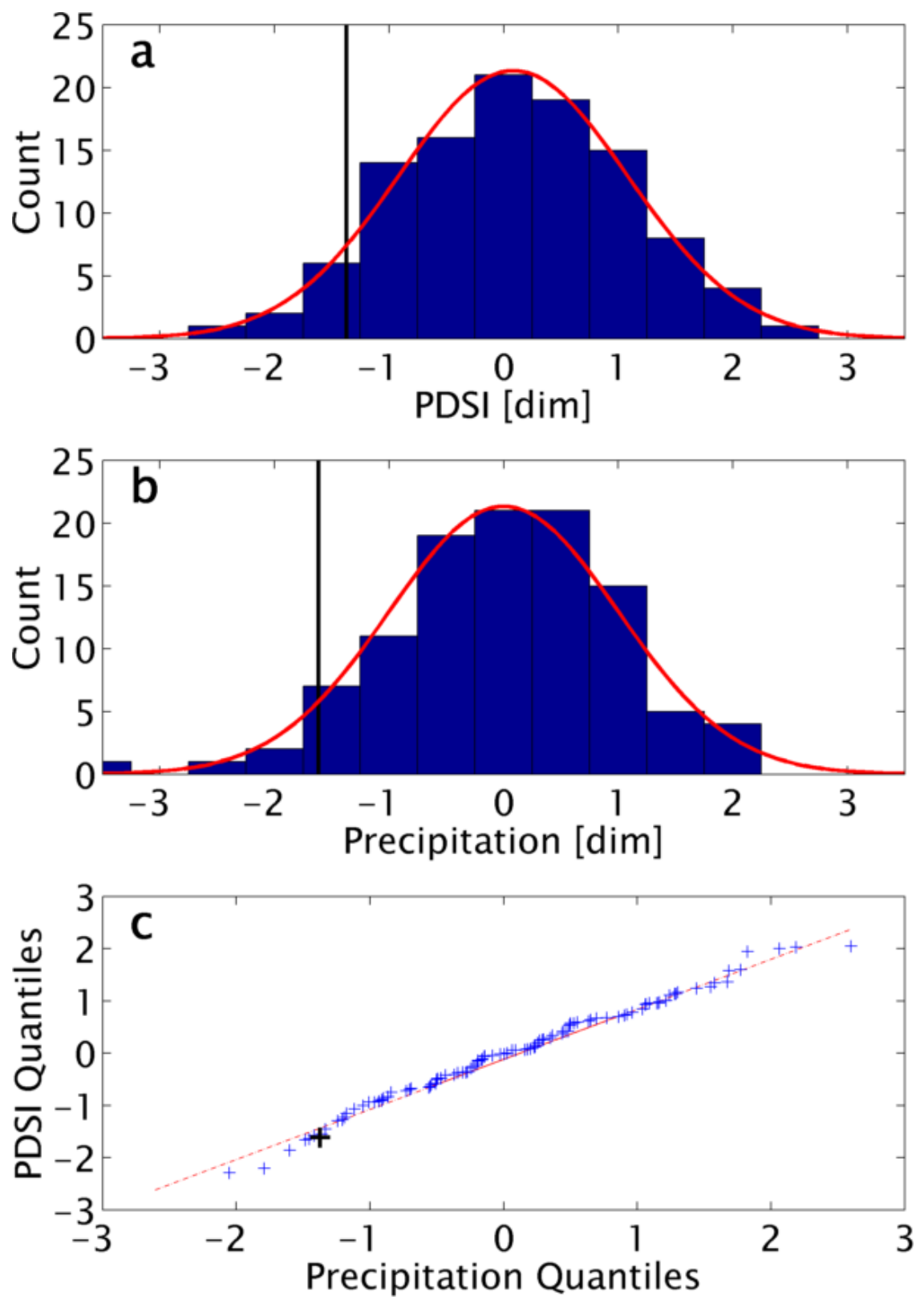

Supplementary Figure 4. Distribution of CMIP5 precipitation $^{30}$ and reconstructed PDSI $^{7}$. Histograms of a, reconstructed summer PDSI and b, CMIP5 summer precipitation over the 107-yr period of overlap (1900 to 2006). Vertical line is the turn of the century drought; red lines are Gaussian densities. Both fields are normalized; PDSI values also zero-centered such that the departures are relative to normal hydrologic conditions ${ }^{19}$. c, Quantile-quantile plot of CMIP5 precipitation and reconstructed PDSI. Large black cross shows the 5-yr average in both fields coincident with the turn of the century drought. Given the goodness of fit between the plotted quantiles and the reference 1:1 the two distributions are highly similar. 


\section{Supplementary Figure 5.}
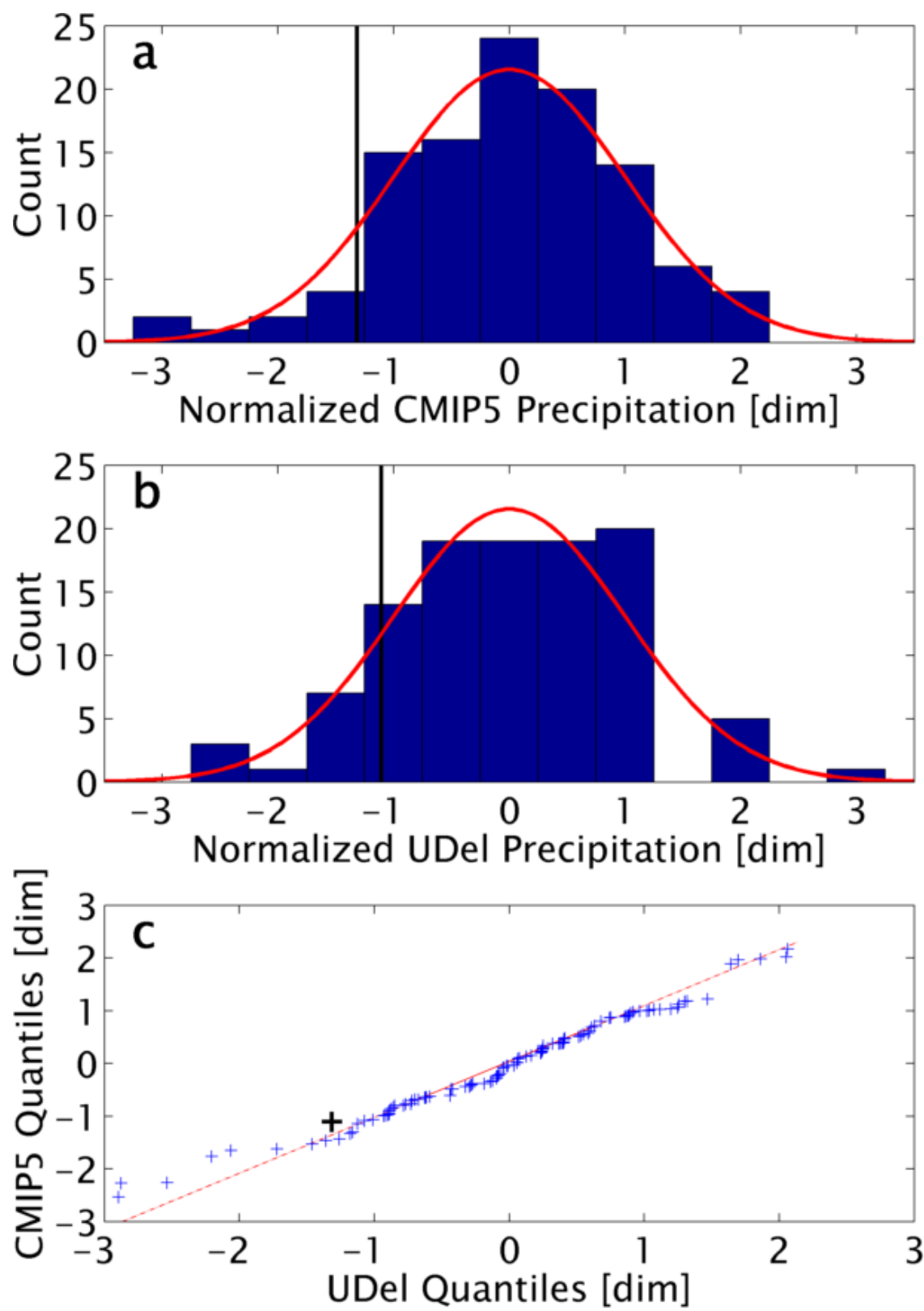

Supplementary Figure 5. Distribution of UDel precipitation and reconstructed PDSI ${ }^{7}$. Histograms of a, reconstructed summer PDSI and $\mathbf{b}$, UDel summer precipitation over the 108-yr period of overlap (1901 to 2008). Vertical line is the turn of the century drought; red lines are Gaussian densities. c, Quantile-quantile plot of CMIP5 and UDel precipitation (http://climate.geog.udel.edu/ climate). Large black cross shows the 5-yr average in both fields coincident with the turn of the century drought. Given the goodness of fit between the plotted quantiles and the reference 1:1 the two distributions are highly similar. Discrepancies are limited to the extreme left-tail $(-2.0 \sigma$ and more extreme). 


\section{References}

31. Schwalm, C. R., Black, T. A., Morgenstern. K. \& Humphreys, E.R. A method for deriving net primary productivity and component respiratory fluxes from tower-based eddy covariance data: a case study using a 17-year data record from a Douglas-fir chronosequence. Glob. Change Biol. 13, 370-385 (2007).

32. Flanagan, L.B. \& Adkinson, A. C. Interacting controls on productivity in a northern Great Plains grassland and implications for response to ENSO events. Glob. Change Biol. 17, 3293-3311 (2011).

33. Goldstein, A. H. et al. Effects of climate variability on the carbon dioxide, water, and sensible heat fluxes above a ponderosa pine plantation in the Sierra Nevada (CA). Agric. For. Meteorol. 101, 113-129 (2000).

34. Wilson, T. \& Meyers, T. Determining vegetation indices from solar and photosynthetically active radiation fluxes. Agric. For. Meteorol. 144, 160-179 (2007).

35. Thomas, C. K. et al. Seasonal hydrology explains interannual and seasonal variation in carbon and water exchange in a semi-arid mature ponderosa pine forest in Central Oregon. J. Geophys. Res. 114, G04006, doi:10.1029/2009JG001010 (2009). 
36. Vickers, D., Thomas, C. \& Law, B. E. Random and systematic $\mathrm{CO}_{2}$ flux sampling errors for tower measurements over forests in the convective boundary layer. Agric. For. Meteorol. 149, 73-83 (2009).

37. Bradford, J. B., Birdsey, R. A., Joyce, L. A. \& Ryan, M. G. Tree age, disturbance history, and carbon stocks and fluxes in subalpine Rocky Mountain forests. Glob. Change Biol. 14, 2882-2897 (2008).

38. Luo, H. et al. Mature semiarid chaparral ecosystems can be a significant sink for atmospheric carbon dioxide. Glob. Change Biol. 13, 386-396 (2007).

39. Scott, R. L., Jenerette, G. D., Potts, D. L. \& Huxman, T. E. Effects of seasonal drought on net carbon dioxide exchange from a woody-plant-encroached semiarid grassland. J. Geophys. Res. 114, G04004, doi:10.1029/2008JG000900 (2009).

40. Ma, S., Baldocchi, D. D., Xu, L. \& Hehn, T. Inter-annual variability in carbon dioxide exchange of an oak/grass savanna and open grassland in California. Agric. For. Meteorol. 147, 157-171 (2007).

41. Falk, M., Wharton, S., Schroeder, M., Ustin, S. \& Paw U, K. T. Flux partitioning in an old-growth forest: seasonal and interannual dynamics. Tree Physiol. 28, 509-520 (2008). 
42. Loveland, T. R. et al. Development of a global land cover characteristics database and IGBP DISCover from 1-km AVHRR data. Int. J. Remote Sens. 21, 1303-1330 (2001).

43. Peters, W. et al. An atmospheric perspective on North American carbon dioxide exchange: CarbonTracker. Proc. Natl. Acad. Sci. 104, 18925-18930 (2007).

44. Rödenbeck, C. Estimating $\mathrm{CO}_{2}$ sources and sinks from atmospheric mixing ratio measurements using a global inversion of atmospheric transport. (Technical Report 6, Max Planck Institute for Biogeochemistry, Jena, 2005). 